Research Article

\title{
Building Organizational Citizenship Behavior through Perceived Organizational Support, Organizational Culture, and Work Motivation
}

\author{
${ }^{1}$ Yulli Arvika Putri, ${ }^{2}$ Setyo Riyanto \\ ${ }^{1}$ Master of Management, Mercu Buana University, Jakarta Indonesia \\ ${ }^{2}$ Lecturer of Mercu Buana University, Jakarta Indonesia
}

\begin{abstract}
:
A Company to reaching these targets requires human resources who have organizational citizenship behavior. The effect of perceived organizational support (POS), organizational culture, and work motivation on organizational citizenship behavior (OCB) of employees at PT Sokonindo Automobile is examined and analyzed in this study. This research was conducted on 104 employee respondents who were involved in several divisions. The research was conducted utilizing a quantitative analysis method with multiple linear regression equation analytical tools and the SPPS version 26 software. The research's empirical findings reveal that perceived organizational support (POS) has a positive and significant impact on PT Sokonindo Automobile employees' ability to build OCB. This effect is much langer and more significant than organizational culture and motivation, which also has a positive and significant influence on building OCB. The findings of this study imply the organizations that continue to provide support to their workers, have harmonious and friendly organizational culture will make employees more enthusiastic (motivated) at work and believe in the organization, which will make employees have high loyalty and voluntarily do work beyond the standard description work (OCB).
\end{abstract}

Keywords: Perceived Organizational Support (POS), Organizational Culture, Work Motivation, Organizational Citizenship Behavior (OCB)

\section{Introduction}

The automotive industry is a mainstay sector. Its development continues to be a priority because it has a very large role in Indonesia's economic growth and is a driving influence for the development of other industries. Seeing the favorable market growth and high public demand for motorized vehicles, PT. Sokonindo Automobile then carried out business development in Indonesia as a manufacturer and the sole agent for the DFSK brand holder. The development of DFSK's business shows excellent results, as can be seen from the increase in production and sales of products that have begun to attract market attention. Seeing the promising business opportunities in the automotive industry requires companies to improve organizational performance with the support of human resources with a level of organizational citizenship behavior (OCB) strong.

OCB expresses the organization according to its goals and values, improves organizational performance, and increases employee productivity. The current conditions at PT Sokonindo Automobile based on the results of a pre-survey conducted in November 2020, it appears that the desire of employees to help do the work of their coworkers is still low, especially when they do not come to work or work is overloaded, there are still employees who are not happy with their work because the salary is not as expected. In addition, there are still employees who spend time talking outside of work during working hours, and there are still employees who don't come on time. This is not following the concept of OCB measurement referring to the dimensions used.

Furthermore, identification of the factors that have a significant effect on employee OCB through presurvey, previous studies have shown that perceived organizational support, organizational culture, and work 
${ }^{1}$ Yulli Arvika Putri et. al/ Building Organizational Citizenship Behavior through Perceived Organizational Support, Organizational Culture, and Work Motivation

motivation affect OCB. Based on these findings, the researchers examined the impact of perceived organizational support (POS), organizational culture, and work motivation on organizational citizenship behavior (OCB) employees of PT. Sokonindo Automobile.

\section{Literature Review}

\section{A. Organizational Citizenship Behavior (OCB)}

Companies need employees who want to work more than just completing tasks according to job descriptions and want to show more performance without expecting rewards. Successful organizations know that employee engagement with OCB is critical [1]. Successful organizations have employees with performance that exceeds the organization's expectations [2]. OCB is defined as the intelligent behavior of an employee that directly shows practical organizational functions without affecting employee productivity [3]. OCB is needed on an ongoing basis for organizational effectiveness [4]. OCB define in 2 types, namely: first, organizational citizenship behavior toward the organization (OCBO), this refers to all actions that assist the company as a whole or specific division, such as attending events for the company's benefit, not complaining at work, and conserving the firm's resources. Organizational citizenship behavior toward the individual (OCBI) can be interpreted as an action aimed at individuals in the organization, such as helping others with work overload [5].

Meanwhile, organizational citizenship behavior (OCB) is defined as a voluntary activity that is not motivated by employee advantages. Still, it is intended only for the organization's benefit in achieving its goals [6]. Podsakoff et al., [7] said the advantages of having OCB organizations include increasing staff and management productivity, saving resources, reducing retention, building better collaboration between groups, increasing organizational effectiveness in maintaining and maintaining staff, enabling the company to adapt to changing surroundings and boosting the organization's operational stability.

Meanwhile, [8] define OCB as voluntary work behavior (discretionary behavior) that contributes positively to the workplace's social and psychological environment. There are five dimensions used to measure organizational citizenship behavior (OCB), namely: (1) Altruism, willingness to assist co-workers in completing the task in extraordinary circumstances, (2) Conscientiousness, describing workers that would go beyond what would be expected when it comes to jobs and responsibilities, (3) Civic virtue, related to employee support for the organization's administrative functions, (4) Courtesy, behavior to alleviate workrelated problems faced by others and (5) Sportsmanship, describing the sportsmanship of a worker towards the organization, this dimension is based on the opinion of Organ et al., [9].

\section{B. Perceived Organizational Support (POS)}

Generally, organizations provide positive types of support to their workers by offering authorization, respect, fair treatment, salary, career growth chances, voice, availability of information, and other benefits that can strengthen work and employee wellbeing. Perceived organizational can be interpreted as an employee's belief in organizational commitment to employees at a certain level [10]. POS is an employee's opinion of how their organization values their work and cares for their well-being, and it has been demonstrated to have considerable benefits for both employees and employers [11]. POS can be in the form of opportunities given to employees to contribute, listen to complaints, be proud of employees' work, and know what employees need [12].

POS is believed to be something that can direct and lead employees to perform well. The POS shows that the company's good and positive treatment of employees is a common obligation, in return for which employees will show their concern and voice for the company [13]. With the POS provided by the company to employees, job satisfaction and employee commitment to their work increase (Eisenberger et al., [14]). In addition, the presence of a strong POS will increase employee obligations to achieve company goals, increase affective commitment to the organization, and these expectations can increase rewards for performance [15].

According to organizational support theory (OST), POS is highly dependent on employees' attributions about the organizational intentions behind their acceptance of favorable or unfavorable treatment [16]. Employees will perceive positive or unfavorable treatment from the organization; this is an indication of how much the organization values employee contributions and cares about their well-being, meaning that POS will be assessed by employees to meet socio-emotional needs, indicating the organization's willingness 
${ }^{1}$ Yulli Arvika Putri et. al/ Building Organizational Citizenship Behavior through Perceived Organizational Support,

Organizational Culture, and Work Motivation

to recognize and appreciate the increased workload, and shows the tendency of the organization to assist when needed by employees to carry out their work effectively [17]. Suppose employees perceive that they have felt perceived organizational support (POS) very high. In that case, employees will establish favorable interactions and opinions about their organization after absorbing their organizational membership into their identity. As a result, employees will feel a sense of belonging and responsibility to contribute and do their best for the company [18].

POS is characterized as an employee's acknowledgment that the organization values his commitment and thinks about employee well-being [17]. When employees feel they are a beneficial resource of an organization, they tend to seek organizational responsibility for their enthusiastic social needs, which is obtained as perceived organizational support (POS) (Ringgle et al., [19]. POS is primarily determined by effective leadership, good HR practices, good working conditions, and fair treatment [11]. Employees who feel perceived organizational support strong will tend to have organizational citizenship behavior strong, reduced delays, and better customer service quality [8].

\section{Organizational Culture}

The level of employee loyalty, compliance, and participation will be influenced by the culture adopted by the organization. Culture rests on the same behavioral norms and values in a group of individuals [20]. Organizational culture is a system of beliefs that grow and develop within the organization and then directs the behavior of people in it [21]. Organizational culture is a system of common meaning shared by all members of an organization that distinguishes it from others [8]. Habits that exist and are carried out in organizations come from organizational values [22].

Furthermore, Ivancevich [23] explains that organizational culture is about employee perceptions and how these perceptions create a pattern of beliefs, values, and expectations. Organizations reflect features that are perceived to exist in the workplace and that occur as a result of organizational actions that are carried out consciously or unconsciously and that are thought to impact the organization's behavior and personality [8]. These conditions make organizations tend to attract and retain people who fit the organizational culture, to form lasting relationships.

Organizational culture is an essential factor in determining the suitability of employees with the organization [20]. Organizational culture represents the collective values, beliefs, and principles held by members of the organization [24]. All members of the organization adopt these beliefs, norms, and values as they carry out their responsibilities. Organizational culture is divided into four hierarchies, namely basic assumptions (the deepest level of culture, which is below the conscious level), values (including values about what should be in the organization), norms (guidelines for the behavior of members of the organization), and artifacts (concrete forms in the form of systems)., procedures, structures, and physical aspects of the organization) [25].

[8] mention seven primary characteristics of organizational culture, and each character is on a continuum from low to high. By assessing an organization based on these seven characteristics, a composite picture of the organization's culture will be obtained, namely: innovation and risk-taking, attention to detail, results in orientation, people orientation, team orientation, aggressiveness, and stability will get a combined picture of the organizational culture.

\section{Work Motivation}

Motivation can be said as a process that explains the strength, direction, and persistence of a person to achieve goals [8]. Motivation is translated as an approach used to achieve a person's high level of performance for the organization's benefit [26]. Motivation is formed from the attitude of employees in dealing with work situations in the company. The elements in motivation are elements of generating, directing, maintaining, showing intensity, being continuous, and having a purpose [27].

Motivation is important to be considered by organizations because, in addition to ability, motivation is needed to produce effective performance [28]. Furthermore, [29] stated the reasons a manager needs to pay attention to motivation, namely:

1) Join the organization, meaning that the organization needs to motivate to bring in the best job applicants to join the company. 
${ }^{1}$ Yulli Arvika Putri et. al/ Building Organizational Citizenship Behavior through Perceived Organizational Support,

Organizational Culture, and Work Motivation

2) Stay with the organization; managers must convince the best employees always to stay and work at the current company.

3) Be engaged at work, meaning that superiors must ensure employees continue to be involved in work.

4) Perform organizational citizenship behavior (OCBs) means having a voluntary attitude of loyalty to the company.

5) Help others, motivate employees to collaborate, and cooperate for the achievement of organizational goals.

There are various types of motivation, one of which is the theory of motivation that is quite popular among management practitioners is the theory proposed by Maslow or often referred to as Maslow's Hierarchy of Needs Theory [30]. This theory states that a person behaves in a certain way because of the encouragement of various needs that must be met. Maslow classified human needs into five types arranged in a hierarchy: physiological needs, safety needs, social needs, esteem needs, and self-actualization needs.

\section{Research methodology}

The design of this study uses a quantitative approach to prove the truth of the theory. The research data was collected using a survey method with a questionnaire as a tool distributed to 104 employees in the PT Sokonindo Automobile environment. The analytical method in this study uses descriptive analysis, instrument testing, classical assumption test, multiple linear regression, and hypothesis testing with SPSS version 26.

\section{Result and Discussion}

\section{A. Instrumen Test}

\section{Validity Test}

A validity testing is used to assess whether or not a questionnaire is valid. The value of $r$ is used in this study as a validity test. The premise for decision-making is that if $r_{\text {count }}>r_{\text {table }}$, the instrument is valid, and if $r_{\text {count }}<$ $\mathrm{r}_{\text {table, }}$, the instrument is invalid. The results are summarized in the table below:

Table 1. Validity Test

\begin{tabular}{|c|c|c|c|c|}
\hline Variable & $\begin{array}{c}\text { Total } \\
\text { Items }\end{array}$ & $\begin{array}{c}\text { Range Value of } \\
\mathrm{r}_{\text {count }}\end{array}$ & $\mathrm{r}_{\text {table }}$ & Description \\
\hline $\begin{array}{c}\text { Perceived Organizational Support } \\
\left(\mathrm{X}_{1}\right)\end{array}$ & 12 & $0,408-0,860$ & 0,191 & Valid \\
\hline Budaya Organisasi $\left(\mathrm{X}_{2}\right)$ & 17 & $0,245-0,686$ & 0,191 & Valid \\
\hline Motivasi Kerja $\left(\mathrm{X}_{3}\right)$ & 11 & $0,243-0,812$ & 0,191 & Valid \\
\hline $\begin{array}{c}\text { Organizational Citizenship Behavior } \\
(\mathrm{Y})\end{array}$ & 24 & $0,227-0,716$ & 0,191 & Valid \\
\hline
\end{tabular}

Source: Data Processed, 2021

According to Tabel 1, this study shown that for all $r_{\text {count }}$ values on each variable $>r_{\text {table }}$, so that all statements used in this research questionnaire are declared valid.

\section{Reliability Test}

The reliability test is used to assess a measurement instrument's consistency when measuring symptoms on the same object. This study bases its decisions on the Cronbach's Alpha formula, which states that if Cronbach's Alpha $>0.70$, the statement item is reliable, and if Cronbach's Alpha $<0.70$, the statement item is not reliable. The following are the results of reliability testing: 
${ }^{1}$ Yulli Arvika Putri et. al/ Building Organizational Citizenship Behavior through Perceived Organizational Support, Organizational Culture, and Work Motivation

Table 2. Reliability Test

\begin{tabular}{|l|c|c|}
\hline \multicolumn{1}{|c|}{ Variable } & $\begin{array}{c}\text { Cronbach's } \\
\text { Alpha }\end{array}$ & Description \\
\hline $\begin{array}{l}\text { Perceived Organizational Support (POS) } \\
\left(\mathrm{X}_{1}\right)\end{array}$ & 0.917 & Reliable \\
\hline Organizational Culture $\left(\mathrm{X}_{2}\right)$ & 0.844 & Reliable \\
\hline Work Motivation $\left(\mathrm{X}_{3}\right)$ & 0.839 & Reliable \\
\hline $\begin{array}{l}\text { Organizational citizenship Behavior } \\
(\mathrm{OCB})(\mathrm{Y})\end{array}$ & 0.826 & Reliable \\
\hline
\end{tabular}

Source: Data Processed, 2021

\section{B. Classical Assumption Test}

This test is used to see if the multiple linear regression model assumptions are met and to interpret the data such that it is more useful in the study. Normality, multicollinearity, and heteroscedasticity tests are among the findings of the classical assumption test.

\section{Normality Test}

The normality test was used to see if the data was normal, the confounding or residual variables in the regression model have a normal distribution, as determined by histogram graphs, normal plot graphs, and the Kolmogorov-Smirnov test.

Table 3. Kolmogorov-Smirnov Test

\begin{tabular}{|l|l|r|}
\hline \multicolumn{2}{|l|}{ One-Sample Kolmogorov-Smirnov Test } & Unstandardized Residual \\
\hline $\mathrm{N}$ & & 104 \\
\hline \multirow{2}{*}{ Normal Parameters } & & 0.0000000 \\
\hline \multirow{2}{*}{ Most Extreme Differences } & Mean & 0.12578233 \\
\cline { 2 - 3 } & Std. Deviation & 0.082 \\
\cline { 2 - 3 } & Absolute & 0.082 \\
\cline { 2 - 3 } & Positive & -0.055 \\
\cline { 2 - 3 } & Negative & 0.082 \\
\hline Test Statistic & & $.082^{\mathrm{c}}$ \\
\hline Asymp. Sig. (2-tailed) & & \\
\hline
\end{tabular}

Source: Data Processed, 2021

The results on the histogram graph show that the distribution of the data on the bar chart has resembled a bell, and the points on a normal plot graph are dispersed along the line and follow the diagonal line, and the residual value is normally distributed. In addition, the Kolmogorov-Smirnov test was also performed with an asymp significance value, the data is normally distributed since Sig (2-tailed) is $0.082>0.05$.

\section{Multicollinearity Test}

The multicollinearity test is used to determine whether independent variables are correlated. The independent variables should not be correlated with a suitable regression model. Multicollinearity does not arise if tolerance $>0.10$ and VIF $<10.00$, but it does occur if tolerance $<0.10$ and VIF $>10.00$. There is no multicollinearity between variables in the regression model in this study since the VIF value of all independent variables is less than 10 , and the value tolerance is more than 0.10 , as shown in the table below: 
${ }^{1}$ Yulli Arvika Putri et. al/ Building Organizational Citizenship Behavior through Perceived Organizational Support, Organizational Culture, and Work Motivation

Table 4. Multicollinearity Test Result

\begin{tabular}{|l|c|c|c|}
\hline \multirow{2}{*}{ Model } & \multicolumn{2}{|c|}{ Collinearity Statistics } & \multirow{2}{*}{ Description } \\
\cline { 2 - 3 } & Tolerance & VIF & \\
\hline (Constant) & 0.360 & 2.774 & $\begin{array}{c}\text { There is no } \\
\text { multicollinearity }\end{array}$ \\
\hline $\begin{array}{l}\text { Perceived Organizational } \\
\text { Support (X1) }\end{array}$ & 0.383 & 2.613 & $\begin{array}{c}\text { There is no } \\
\text { multicollinearity }\end{array}$ \\
\hline Budaya Organisasi (X2) & 0.394 & 2.536 & $\begin{array}{c}\text { There is no } \\
\text { multicollinearity }\end{array}$ \\
\hline Motivasi Kerja (X3) & & \\
\hline
\end{tabular}

Source: Data Processed, 2021

\section{Heteroscedasticity test}

The heteroscedasticity test checks the pattern of the scatter diagram to see if there is an inequality of variance from the residuals or other data in the regression model. According to the results of this study, the points on the diagram are scattered and do not form a pattern or are randomly distributed, indicating that the regression model does not have heteroscedasticity as shown below:

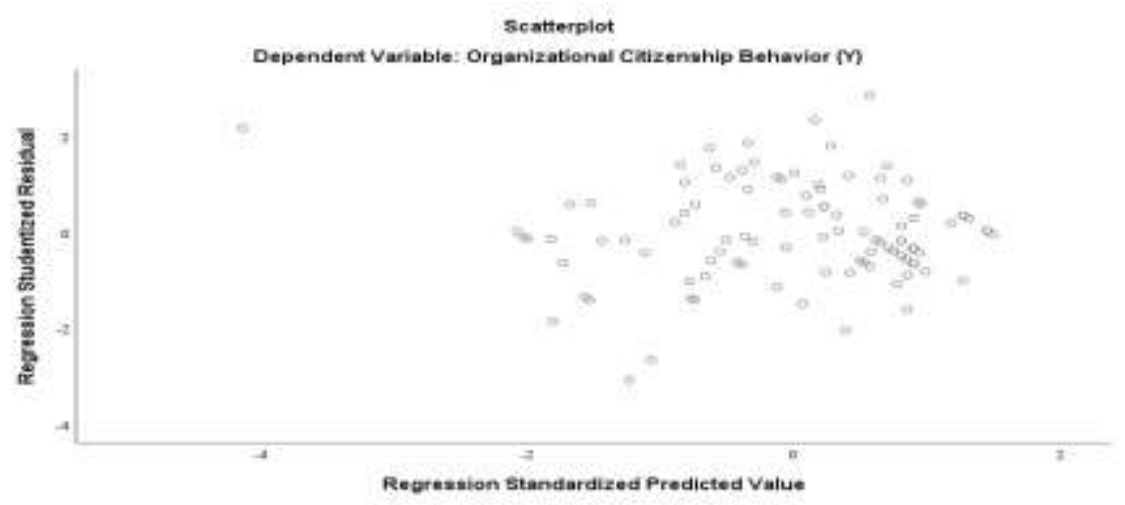

Figure 1. Heteroscedasticity Test (Scatter Diagram)

Source: Data Processed, 2021

\section{Multiple Linear Regression Test}

Multiple linear regression analysis is used to measure the influence between two or more independent variables or on one dependent variable using SPSS 26, and the results of the regression equation coefficients are as follows:

$$
Y=1,767+0,250\left(X_{1}\right)+0,168\left(X_{2}\right)+0,151\left(X_{3}\right)
$$

1. The value constant is 1.767 , the value of OCB (Y) is 1.767 if the variables perceived organizational support (POS), organizational culture, and job motivation are all considered to be zero.

2. The regression coefficient variable perceived organizational support (POS) ( $\left.\mathrm{X}_{1}\right)$ is 0.250 , assuming variable organizational culture $\left(\mathrm{X}_{2}\right)$, work motivation $\left(\mathrm{X}_{3}\right)$, and the constant is 0 (zero), organizational citizenship behavior (OCB) will increase by 0.250 anytime the variables increase. This indicates that the variable perceived organizational support (POS) has a positive impact on organizational citizenship behavior (OCB), therefore the higher the POS, the more OCB workers there will be.

3. The regression coefficient variable organizational culture (X2) is 0.168 means that whenever an increase in the variable of organizational culture by 1 (one) unit assuming a variable perceived organizational support (POS) $\left(\mathrm{X}_{1}\right)$, work motivation $\left(\mathrm{X}_{3}\right)$, and the constant is 0 (zero). Organizational citizenship behavior $(\mathrm{OCB})$ will increase by 0.168 . This indicates that the organizational culture variable has a positive impact on $\mathrm{OCB}$, implying that the stronger the organizational culture, the higher the organizational citizenship behavior of workers. 
${ }^{1}$ Yulli Arvika Putri et. al/ Building Organizational Citizenship Behavior through Perceived Organizational Support, Organizational Culture, and Work Motivation

4. The work motivation variable $\left(\mathrm{X}_{3}\right)$ has a regression coefficient of 0.151 , which means that if the work motivation variable is increased by 1 (one) unit with the assumption that the variables perceived organizational support (POS) $\left(\mathrm{X}_{1}\right)$, organizational culture $\left(\mathrm{X}_{2}\right)$, and the constant are all 0 (zero), organizational citizenship behavior (OCB) increases by 0.151 . This indicates that the work motivation variable has a positive impact on organizational citizenship behavior, implying that the higher the employee's work motivation, the higher the organizational citizenship behavior (OCB).

\section{Hypothesis Test}

\section{Partial Test (T-Test)}

The t-test was used to indicate that the independent variable had a partial effect on one dependent variable, as shown in the table below:

\section{Tabel 5. Multiple Linear Regression and T-Test}

\begin{tabular}{|c|c|c|c|c|c|c|}
\hline \multirow[b]{2}{*}{ Model } & \multicolumn{2}{|c|}{$\begin{array}{l}\text { Unstandardized } \\
\text { Coefficients }\end{array}$} & \multirow{2}{*}{\begin{tabular}{l} 
Standardize \\
$\mathrm{d}$ \\
Coefficients \\
\multicolumn{1}{c}{ Beta }
\end{tabular}} & \multirow{2}{*}{$\mathrm{t}$} & \multirow{2}{*}{ Sig. } & \multirow{2}{*}{$\begin{array}{l}\text { Descriptions of } \\
\text { Influence }\end{array}$} \\
\hline & $\mathrm{B}$ & $\begin{array}{l}\text { Std. } \\
\text { Error }\end{array}$ & & & & \\
\hline (Constant) & 1,767 & 0,155 & & $\begin{array}{c}11,4 \\
23\end{array}$ & 0,000 & Positive and Significant \\
\hline $\begin{array}{l}\text { Perceived } \\
\text { organizational Support } \\
\left(\mathrm{X}_{1}\right)\end{array}$ & 0,250 & 0,043 & 0,479 & $\begin{array}{c}5,85 \\
3\end{array}$ & 0,000 & Positive and Significant \\
\hline $\begin{array}{l}\text { Budaya Organisasi } \\
\left(\mathrm{X}_{2}\right)\end{array}$ & 0,168 & 0,063 & 0,211 & $\begin{array}{c}2,64 \\
9\end{array}$ & 0,009 & Positive and Significant \\
\hline Motivasi Kerja $\left(\mathrm{X}_{3}\right)$ & 0,151 & 0,045 & 0,263 & $\begin{array}{c}3,35 \\
4\end{array}$ & 0,001 & Positive and Significant \\
\hline
\end{tabular}

Source: Data Processed, 2021

According to the $t$ values on Table 5, all of the independent variables have a partially positive and significant effect on the dependent variable, with the variable perceived organizational support (X1) having the most effect on the variable organizational citizenship behavior (Y) seen from the Standardized Coefficients Beta dan $t$ value has the largest values.

\section{Simultaneous Test (F Test)}

The $\mathrm{F}$ test is used to see how the independent variable affects simultaneously the dependent variable at the same time. $\mathrm{F}_{\text {count }}$ was obtained using SPSS version 26 software, then it will be compared with the $F_{\text {table }}$ with a significance level of $5 \%$ is 2.696 . According to the results of this study, the value $\mathrm{F}_{\text {count }}$ is more than $\mathrm{F}_{\text {table }}$ $(104.533>2.696)$ and sig. $0.000<0.05$, it was determined that the variables of perceived organizational support (POS) $\left(\mathrm{X}_{1}\right)$, organizational culture $\left(\mathrm{X}_{2}\right)$, dan work motivation $\left(\mathrm{X}_{3}\right)$ have a simultaneity positive and significant effect on organizational citizenship behavior (OCB) (Y) as shown below:

Table 6. F Test

\begin{tabular}{|l|l|c|c|c|c|c|}
\hline Model & & $\begin{array}{c}\text { Sum of } \\
\text { Squares }\end{array}$ & df & Mean Square & F & Sig. \\
\hline 1 & Regression & 5,110 & 3 & 1,703 & 104,533 & $.000^{\mathrm{b}}$ \\
\hline & Residual & 1,630 & 100 & 0,016 & & \\
\hline & Total & 6,740 & 103 & & & \\
\hline
\end{tabular}

Source: Data Processed, 2021

\section{Determination Test $\left(\mathbf{R}^{2}\right)$}


${ }^{1}$ Yulli Arvika Putri et. al/ Building Organizational Citizenship Behavior through Perceived Organizational Support, Organizational Culture, and Work Motivation

The influence of independent variables perceived organizational support (POS) ( $\left.\mathrm{X}_{1}\right)$, organizational culture $\left(\mathrm{X}_{2}\right)$, and work motivation $\left(\mathrm{X}_{3}\right)$ on the dependent variable organizational citizenship behavior $(\mathrm{OCB})(\mathrm{Y})$ is determined using the determination test (R2), as shown in the table below:

Table 7. Determination Test $\left(\mathbf{R}^{2}\right)$

\begin{tabular}{|c|c|c|c|c|}
\hline Model & $\mathrm{R}$ & R Square & Adjusted R Square & Std. Error of the Estimate \\
\hline 1 & $.871^{\mathrm{a}}$ & 0.758 & 0.751 & 0.12766 \\
\hline
\end{tabular}

Source: Data Processed, 2021

This shows that the variable perceived organizational support (POS) (X1), perceived organizational support (POS) $\left(\mathrm{X}_{1}\right)$, organizational culture $\left(\mathrm{X}_{2}\right)$, and work motivation $\left(\mathrm{X}_{3}\right)$, explain $75.1 \%$ of the variance in the dependent variable, organizational citizenship behavior (OCB) (Y), and $24.9 \%$ is examined by other variables not covered in this study. Furthermore, the $\mathrm{R}$ value, or correlation coefficient, is 0.871 , indicating that the link between dimensions is quite strong.

\section{Correlation between Dimensions}

On the independent variables perceived organizational support (POS) $\left(\mathrm{X}_{1}\right)$, organizational culture $\left(\mathrm{X}_{2}\right)$, and work motivation $\left(\mathrm{X}_{3}\right)$, testing is utilized to evaluate whether or not the link between dimensions is strong on the dependent variable organizational citizenship behavior (OCB) (Y). The table below shows the results of the relationship strength test.

Table 8. Correlation Matrix between Dimensions

\begin{tabular}{|c|c|c|c|c|c|c|}
\hline \multirow[t]{2}{*}{ Variable } & \multirow[t]{2}{*}{ Dimensions } & \multicolumn{5}{|c|}{ Organizational Citizenship Behavior (Y) } \\
\hline & & $\begin{array}{c}\text { Altruis } \\
\mathrm{m} \\
\left(\mathrm{Y}_{1}\right)\end{array}$ & $\begin{array}{c}\text { Conscientiousn } \\
\text { ess } \\
\left(\mathrm{Y}_{2}\right) \\
\end{array}$ & $\begin{array}{c}\text { Sportsmans } \\
\text { hip } \\
\left(\mathrm{Y}_{3}\right)\end{array}$ & $\begin{array}{c}\text { Courtes } \\
\mathrm{y} \\
\left(\mathrm{Y}_{4}\right)\end{array}$ & $\begin{array}{l}\text { Civic } \\
\text { virtue } \\
\left(\mathrm{Y}_{5}\right) \\
\end{array}$ \\
\hline \multirow{3}{*}{$\begin{array}{c}\text { Perceived } \\
\text { Organization } \\
\text { al Support } \\
\left(\mathrm{X}_{1}\right)\end{array}$} & Fairness $\left(\mathrm{X}_{1.1}\right)$ & 0.509 & 0.517 & 0.684 & 0.270 & 0.551 \\
\hline & $\begin{array}{l}\text { Organizational } \\
\text { Reward and Job } \\
\text { Condition }\left(\mathrm{X}_{1.2}\right)\end{array}$ & 0.464 & 0.515 & 0.706 & 0.360 & 0.493 \\
\hline & $\begin{array}{l}\text { Supervisory Support } \\
\left(\mathrm{X}_{1.3}\right)\end{array}$ & 0.389 & 0.455 & 0.392 & 0.149 & 0.270 \\
\hline \multirow{7}{*}{$\begin{array}{l}\text { Organization } \\
\text { al Culture } \\
\qquad\left(\mathrm{X}_{2}\right)\end{array}$} & $\begin{array}{l}\text { Innovation and risk- } \\
\text { taking }\left(\mathrm{X}_{2.1}\right)\end{array}$ & 0.125 & 0.558 & 0.421 & 0.329 & 0.341 \\
\hline & $\begin{array}{l}\text { Attention to detail } \\
\left(\mathrm{X}_{2.2}\right)\end{array}$ & 0.013 & 0.199 & 0.081 & 0.294 & 0.164 \\
\hline & $\begin{array}{l}\text { Result orientation } \\
\left(\mathrm{X}_{2.3}\right)\end{array}$ & 0.091 & 0.014 & 0.151 & 0.379 & 0.215 \\
\hline & $\begin{array}{l}\text { People orientation } \\
\left(\mathrm{X}_{2.4}\right)\end{array}$ & 0.476 & 0.642 & 0.731 & 0.254 & 0.423 \\
\hline & $\begin{array}{l}\text { Team orientation } \\
\left(\mathrm{X}_{2.5}\right)\end{array}$ & 0.219 & 0.344 & 0.348 & 0.085 & 0.321 \\
\hline & Aggression $\left(\mathrm{X}_{2.6}\right)$ & 0.127 & 0.438 & 0.571 & 0.204 & 0.215 \\
\hline & Stability $\left(\mathrm{X}_{2.7}\right)$ & 0.424 & 0.442 & 0.675 & 0.259 & 0.349 \\
\hline \multirow{3}{*}{$\begin{array}{c}\text { Work } \\
\text { Motivation } \\
\left(\mathrm{X}_{3}\right)\end{array}$} & $\begin{array}{l}\text { Physiological needs } \\
\left(\mathrm{X}_{3.1}\right)\end{array}$ & 0.386 & 0.394 & 0.536 & 0.040 & 0.314 \\
\hline & Social needs $\left(\mathrm{X}_{3.2}\right)$ & 0.136 & 0.336 & 0.064 & 0.075 & 0.121 \\
\hline & Esteem needs $\left(\mathrm{X}_{3.3}\right)$ & 0.386 & 0.539 & 0.699 & 0.279 & 0.478 \\
\hline
\end{tabular}


${ }^{1}$ Yulli Arvika Putri et. al/ Building Organizational Citizenship Behavior through Perceived Organizational Support, Organizational Culture, and Work Motivation

\begin{tabular}{|l|l|c|c|c|c|c|}
\hline & $\begin{array}{l}\text { Self-actualization } \\
\text { needs }\left(\mathrm{X}_{3.4}\right)\end{array}$ & 0.403 & 0.510 & 0.574 & 0.137 & 0.439 \\
\hline & & & & & & \\
\hline
\end{tabular}

Source: Data Processed, 2021

The table shows the correlation between the dimensions of the calculation results with a strong influence to variable perceived organizational support $\left(\mathrm{X}_{1}\right)$ on variable OCB $(\mathrm{Y})$ is organizational reward and job condition dimensions on sportsmanship dimensions with a value of 0.706 , meaning that the current conditions for organizational citizenship behavior (OCB), especially for the dimension sportsmanship employee at PT Sokonindo Automobile, are heavily influenced by organizational rewards and job conditions. This is in accordance with the findings of [31] study, which found that organizational rewards and employment circumstances have the greatest impact on OCB. Meanwhile, the very low relationship is seen in the supervisory support on courtesy dimension. This illustrates that the role of supervisor or superior has not functioned properly.

The highest correlation on organizational culture variable $\left(\mathrm{X}_{2}\right)$ with $\mathrm{OCB}(\mathrm{Y})$ is on the orientation dimension of people who have a strong relationship with the dimension sportsmanship with a value of 0.731 . This thing describes every management decision in the company. Suppose it can influence employees in the company always to come to work on time, use the ability to work properly and correctly, and express opinions, criticisms, and suggestions. In that case, employees are more tolerant of conditions in the company. This is in accordance with the findings of [32] study, which found that organizational culture has a positive and significant influence on OCB, especially on indicators of human orientation. While there is a link between the dimensions of innovation and risk-taking, attention to detail, and result orientation, and the dimensions of altruism, the correlation is quite low. This illustrates that the contribution of the dimensions of innovation and risk-taking, attention to detail, and results in orientation still lacks to improve OCB.

At work motivation $\left(\mathrm{X}_{3}\right)$ on $\mathrm{OCB}(\mathrm{Y})$, a strong correlation relationship is indicated by the dimensions of the dimensional requirements award sportsmanship with a value of 0.699 . The correlation illustrates that the company's awarding of employees in the form of additional wages, creating the fulfillment of job security needs, and proper treatment greatly affects the formation of OCB. However, there is still a contribution from the dimension of the social need, which has a weak relationship with the dimension courtesy. This shows a sense of solidarity between fellow employees in the company, and social interactions between co-workers and superiors have not been well established. This affects the low OCB, especially in the dimension of courtesy.

\section{Conclutions and recommendations}

\section{A. Conclutions}

1) Organizational citizenship behavior of PT Sokonindo Automobile workers is positively and significantly influenced by perceived organizational support (POS). Perceived organizational support (POS) has the greatest influence on the formation of OCB, especially in terms of employees already feeling the high support provided by the organization for the rewards received by employees from the work that is deemed appropriate, and the company already has a safe, comfortable working environment. However, in terms of supervisory support, the company has not yet functioned properly.

2) Organizational citizenship behavior of PT Sokonindo Automobile workers is positively and significantly influenced by organizational culture, especially the company's orientation towards people where the company can influence employees to always come to work on time, use the ability to work well, and correctly, however, innovation and risk-taking, attention to detail, and result orientation are still lacking and have not been applied adequately.

3) Organizational citizenship behavior of PT Sokonindo Automobile workers is positively and significantly influenced by work motivation, especially on the need for awards given by the company with additional wages and proper treatment. However, social relations, a sense of solidarity between social interactions among co-workers and superiors have not been well established.

4) Organizational citizenship behavior positively significantly and simulant influenced by perceived organizational support (POS), organizational culture, and work motivation. Perceived organizational 
${ }^{1}$ Yulli Arvika Putri et. al/ Building Organizational Citizenship Behavior through Perceived Organizational Support, Organizational Culture, and Work Motivation

support (POS), organizational culture, and strong work motivation are expected to build strong organizational citizenship behavior in the employees of PT Sokonindo Automobile.

\section{B. Recommendations}

Basis on the results, the authors provide the following suggestions for improving organizational citizenship behavior (OCB) among employees:

1) Companies need to increase support for employees, especially for rewards and working conditions in the organization, by appreciating employee contributions through rewards, recognition, and salaries and providing equal opportunities for employees to get promotions. Companies must clarify the system of giving wages or rewards that are currently running, clarifying the promotion system, especially performance appraisal and evaluation. In addition, there is a dimension of supervisory support that needs attention because it has not been appropriately functioned to improve employee OCB through the provision of a training Leadership Development Program for superiors, and GMD must evaluate the attitude of superiors and provide coaching that superiors can provide better supervision.

2) The company needs to strengthen the dimensions of people-orientation to improve the OCB of employees at PT Sokonindo Automobile, which is expected the company to be more open to receiving criticism and suggestions from employees and evaluate policies related to employee discipline rules. In addition, some dimensions need attention, namely the dimensions of attention to detail, result orientation, and innovation, and risk-taking, where the leader must give more attention and care to employees through providing direction in doing work or opening opportunities for discussion if employees cannot complete a job, give confidence to employees in making decisions.

3) Companies need to strengthen the dimension of the need for appreciation by giving appreciation to the hard work of employees who achieve the company's targets, and this can be done by adding. In addition, there is a dimension that needs attention because it has not been well developed in the company. Namely, the dimension of social needs withholds a program gathering every year. Companies can also form communities or forums that are tailored to the interests or hobbies of employees, thus enabling employees to open up opportunities to build employee social relationships, so that deeper interactions occur between employees outside of working hours.

4) Future researchers are expected to include other variables that have a substantial effect on developing organizational citizenship behavior.

\section{References}

1. F. Abed and A. H. Elewa, "The Relationship between Organizational Support, Work Engagement and Organizational Citizenship Behavior as Perceived by Staff Nurses at Different Hospitals," J. Nurs. Heal. Sci., vol. 5, no. 4, pp. 113-123, 2016, doi: 10.9790/1959-050405113123.

2. Adrianto and S. Riyanto, "The Effect of Organizational Commitment, Employee Engagement, and Organizational Citizenship Behavior on Employee Performance at PT. Titan Infra Energy - Head Office," J. Humanit. Soc. Sci., vol. 25, no. 1, pp. 22-31, 2020, doi: 10.9790/0837-2501092231.

3. A. Acaray and A. Akturan, "The Relationship between Organizational Citizenship Behavior and Organizational Silence," Procedia - Soc. Behav. Sci., vol. 207, pp. 472-482, 2015, doi: 10.1016/j.sbspro.2015.10.117.

4. M. Reza, Suryadi, and Nurjannah, "Personality and Motivation: Its Effect on Organizational Citizenship Behavior (OCB) Staff in Human Resources Development Agency of Ministry of Public Works and Housing," Int. J. Sci. Res., vol. 7, no. 5, pp. 110-113, 2018, doi: 10.21275/ART20182112.

5. T. A. El Badawy, M. M. Kamel, and M. M. Magdy, "Exploring the Relationship between Organizational Culture, Job Satisfaction and Organizational Citizenship Behavior," Int. J. Hum. Resour. Stud., vol. 6, no. 4, pp. 20-33, 2016, doi: 10.5296/ijhrs.v6i4.9939.

6. I. M. D. Mahendra and I. B. K. Surya, "Pengaruh Iklim Organisasi, Motivasi Kerja dan Keadilan Organisasi terhadap Organizational Citizenship Behavior (OCB)," E-Jurnal Manaj. Unud, vol. 6, no. 9, pp. 4659-4688, 2017.

7. H. Ebrahimpour, A. Zahed, A. Khaleghkhah, and M. B. Sepehri, "A Survey Relation between 
${ }^{1}$ Yulli Arvika Putri et. al/ Building Organizational Citizenship Behavior through Perceived Organizational Support,

Organizational Culture, and Work Motivation

Organizational Culture and Organizational Citizenship Behavior,” Procedia - Soc. Behav. Sci., vol. 30, pp. 1920-1925, 2011, doi: 10.1016/j.sbspro.2011.10.373.

8. S. P. Robbins and T. A. Judge, Organizational Behavior (17th) Edition. New Jersey: Pearson Education Limited, 2017.

9. Y. R. P. Husodo, "Pengaruh Budaya Organisasi terhadap Organizational Citizenship Behavior (OCB) dengan Kepuasan Kerja sebagai Variabel Intervening Pada PT Jatim Indo Lestari," Agora, vol. 6, no. 1, pp. 1-8, 2018.

10. S. A. Mohamed and M. Ali, "Effects of Perceived Organizational Support on Employees' Job Satisfaction," Int. J. Res. Rev., vol. 3, no. 3, pp. 1-13, 2016.

11. R. Eisenberger, G. P. Malone, and W. D. Presson, "Optimizing Perceived Organizational Support to Enhance Employee Engagement," Soc. Hum. Resour. Manag. Soc. Ind. Organ. Psychol., pp. 1-22, 2016.

12. D. La Husen, A. Hakim, and M. Masri, "The Effect of Perceived Organizational Support ( POS ) of Performance Educated by Organizational Citizenship Behavior ( OCB ) in Employees PT . Kendari Express," IOSR J. Bus. Manag., vol. 21, no. 7, pp. 15-28, 2019, doi: 10.9790/487X-2107021528.

13. Y. Fristin, U. Nimran, M. Al Musadieq, and H. N. Utami, "The Relationship Among Superleader, Perceived Organizational Support and Work Performance Mediated By Work Satisfaction and Employee," Int. J. Recent Technol. Eng., vol. 8, no. 4, pp. 2406-2415, 2019, doi: 10.35940/ijrte.d7176.118419.

14. K. Metria and I. G. Riana, "Pengaruh Dukungan Organisasi terhadap Komitmen Organisasional dan Kinerja Pegawai," E-Jurnal Ekon. dan Bisnis Univ. Udayana, vol. 7, no. 9, pp. 2117-2146, 2018.

15. V. S. Mary, "Impact of Perceived Organizational Support on Job Satisfaction - A Study Report," Int. J. Appl. Sci. Eng., vol. 3, no. 2, pp. 45-48, 2015.

16. J. N. Kurtessis, R. Eisenberger, M. T. Ford, L. C. Buffardi, K. A. Stewart, and C. S. Adis, "Perceived Organizational Support: A Meta-Analytic Evaluation of Organizational Support Theory," $J$. Manage., vol. 20, no. 10, pp. 1-31, 2015, doi: 10.1177/0149206315575554.

17. L. Rhoades and R. Eisenberger, "Perceived Organizational Support: A Review of the Literature," J. Appl. Psychol., vol. 87, no. 4, pp. 698-714, 2002, doi: 10.1037/0021-9010.87.4.698.

18. M. Claudia, "The Influence of Perceived Organizational Support, Job Satisfaction and Organizational Commitment toward Organizational Citizenship Behavior (A Study of The Permanent Lecturers at University of Lambung Mangkurat, Banjarmasin)," J. Indones. Econ. Bus., vol. 33, no. 1, pp. 23-45, 2018.

19. I. S. Najeemdeen, B. T. Abidemi, F. D. Rahmat, and B. D. Bulus, "Perceived Organizational Culture and Perceived Organizational Support on Work Engagement," Discov. Publ., vol. 54, no. 275, pp. 411-418, 2018.

20. J. Suwaryo, H. K. K. Daryanto, and A. Maulana, "Organizational Culture Change and its Effect on Change Readiness through Organizational Commitment," Int. J. Adm. Sci. Organ., vol. 22, no. 1, pp. 68-78, 2015.

21. F. Putrie and M. Nursalim, "Hubungan antara Persepsi Dukungan Organisasi dan Budaya Organisasi dengan Organizational Citizenship Behavior (OCB) Pada Karyawan PT. Pertamina UPMS V Surabaya," J. Psikol. Teor. dan Terap., vol. 3, no. 2, pp. 141-148, 2013.

22. S. Riyanto and M. Panggabean, "The Impact of Leadership, Organizational Culture and Organizational Climate on Employee Job Satisfaction (Case Study: PT Garuda Indonesia (Persero) Tbk)," Adv. Econ. Bus. Manag. Res., vol. 120, pp. 28-36, 2019.

23. I. Wellem, "Analisis Budaya Organisasi dengan Menggunakan Metode Organizational Culture Assessment Instrument (OCAI) pada Perusahaan Daerah Air Minum (PDAM) Kabupaten Sikka," J. Projemen UNIPA Maumere, vol. 6, no. 1, pp. 1-22, 2019.

24. A. Nikpour, "The Impact of Organizational Culture on Organizational Performance: The Mediating Role of Employee's Organizational Commitment," Int. J. Organ. Leadersh., vol. 6, no. 2017, pp. 6572, 2016.

25. T. G. Cummings and C. G. Worley, Organization Development \& Change, 9th ed. South-Western: Cengage Learning, 2009. 
${ }^{1}$ Yulli Arvika Putri et. al/ Building Organizational Citizenship Behavior through Perceived Organizational Support,

Organizational Culture, and Work Motivation

26. S. Shaaban, "The Impact of Motivation on Organizational Citizenship Behaviour (OCB): The Mediation Effect of Employees' Engagement," J. Hum. Resour. Manag., vol. 6, no. 2, pp. 58-66, 2018, doi: 10.11648/j.jhrm.20180602.13.

27. Wibowo, Budaya Organisasi : Sebuah Kebutuhan untuk Meningkatkan Kinerja Jangka Panjang, 2nd ed. Jakarta: Rajawali Pers, 2016.

28. S. Farahdiba and L. C. Nawangsari, "Analysis over Human Resources Information System Implementation which Influenced Competence and Motivation in Improving Employee Performance at One of Mineral Mining and Coal Contractor Company," Dinasti Int. J. Manag. Sci., vol. 2, no. 1, pp. 26-36, 2020, doi: 10.31933/dijms.v2i1.

29. A. Kinicki and M. Fugate, Organizational Behavior: A Practical, Problem-Solving Approach, 2nd ed., vol. 64, no. 2. New York, 2018.

30. A. A. P. Mangkunegara, Manajemen Sumber Daya Manusia Perusahaan. Bandung: Remaja Rosdakarya, 2015.

31. S. Wulandari and C. Andriani, "Pengaruh Perceived Organizational Support terhadap Organizational Citizenship Behavior dengan Komitmen Organisasional sebagai Variabel Mediasi pada Perawat Rawat Inap Rumah Sakit Tentara Dr . Reksodiwiryo Padang," J. Kaji. Manaj. dan Wirausaha, vol. 01, no. 02, pp. 73-82, 2019.

32. R. M. Utami and Palupiningdyah, "Pengaruh Kepuasan Kerja, Budaya Organisasi, dan Keterlibatan Kerja pada Organizational Citizenship Behavior," Manag. Anal. J. 5, vol. 5, no. 4, pp. 362-374, 2016. 